\title{
Identification of Methylated Cytosine from Archival Formalin-Fixed Paraffin-Embedded Specimens
}

\author{
Sohei Kitazawa, Riko Kitazawa, and Sakan Maeda \\ Second Department of Pathology, Kobe University School of Medicine, Kobe, Japan
}

$T$ he use of archival formalin-fixed, paraffinembedded pathological specimens for molecular biological analysis has become increasingly important. Also, DNA methylation is one of the essential epigenetical mechanisms controlling gene expression. We show that formalin fixation, for up 72 hours, does not impair the accessibility of methylated cytosine, and that DNA degradation, as an adverse effect of formalin fixation, is an advantage in the PCR-mediated detection of methylated cytosine. With this technique, retrospective and morphology-oriented epigenetical studies as well as clonal analysis are possible using microdissected samples from paraffin-embedded pathological specimens.

As an epigenetic event, DNA methylation, especially cytosine methylation, plays a major role in the regulation of sequential and tissue-specific expression of the gene (Lewis et al, 1992). In this study, we first analyzed the effect of the formalin-fixation on the accessibility of the methylated cytosine, then applied the agarosebead-mediated bisulfite modification and the PCR technique to investigate the methylation status of the 5 '-flanking region of the rat cyclin D1 gene from microdissected fragments of paraffin sections.

Two established cell lines, K4D and K4D16 (Kitazawa et al, 1999), were used as a model for assessing the effects of the fixative condition on the detection of methylated-cytosine residues. Freshly prepared $30 \mu \mathrm{l}$ of $10 \mathrm{~mm}$ hydroquinone and $520 \mu \mathrm{l}$ of $3 \mathrm{M}$ sodium bisulfite at $\mathrm{pH} 5$ were added to the extracted DNA. Each sample was incubated under mineral oil at $50^{\circ} \mathrm{C}$ for 16 hours. Modification was completed by $\mathrm{NaOH}$ (final concentration, $0.3 \mathrm{M}$ ) treatment for 5 minutes at room temperature, then by ethanol precipitation. Bisulfite-modified DNA (100 ng) was amplified with PCR using the following primers:

5'-GTGTTGATGAAATTGAAAGAAGTTG-3': sense

5'-ACTTTACAACTTCAACAAAACTCCCCTAT-3':

anti-sense

The PCR condition was as follows: 30 cycles of $94^{\circ} \mathrm{C}$ for 30 seconds, $60^{\circ} \mathrm{C}$ for 30 seconds, $72^{\circ} \mathrm{C}$ for 30 seconds, and the final elongation step for 5 minutes at $72^{\circ} \mathrm{C}$. When intact DNA was fragmented, a clear PCR product

Received November 16, 1999.

Address reprint requests to: Dr. S. Kitazawa, Second Department of Pathology, Kobe University School of Medicine, 7-5-1 Kusunoki-cho, Chuo-ku, Kobe S650-0017, Japan. Fax: 8178362 0297; E-mail: kitazawa@med.kobe-u.ac.jp of 560 bp was formed (Fig. 1, Lane 2, EcoRI + 0). When cells were fixed with $10 \%$ formalin for 24,48 , and 72 hours, a clear PCR product was formed without predigestion with EcoRI restriction endonuclease (Fig. 1, upper panel, Lanes 3 to 5). No PCR products were, however, formed when fixation with $10 \%$ formalin reached 120 hours (Fig. 1, upper panel, Lane 6). The PCR products yielded from samples after 72 hours of fixation with $10 \%$ formalin were eluted, purified, and analyzed by sequencing. The methylated cytosine in the 19th CpG locus in the K4D cell line was detectable from the DNA extracted from K4D fixed with 10\% formalin for 72 hours (Fig. 1, lower panel, arrows). When K4D and K4D16 cells were mixed and injected intravenously into Long-Evans rats, the cells developed numerous metastatic nodules resembling myeloblastoma in most of the organs. The lung tissues were removed and fixed with $10 \%$ formaldehyde for 24 hours and embedded in paraffin. Sections were cut, and selected areas of the interest were microdissected and collected in $1.5 \mathrm{ml}$ microcentrifuge tubes. The samples were deparaffinized for a total of 30 minutes in $1 \mathrm{ml}$ xylene before dehydration with $100 \%$ ethanol in the microcentrifuge tubes. The samples were further dehydrated in a vacuum for 10 minutes, redissolved, and shredded into minute pieces by pipetting in $10 \mu \mathrm{l}$ nuclease-free water, then immediately mixed with an equal amount of preheated $\left(80^{\circ} \mathrm{C}\right)$ and melted $3.2 \%$ low-temperature melting agarose (SeaPlaque, Takara, Kyoto, Japan) by pipetting. The agarose beads were made by dropping $5 \mu$ l of the mixed samples into a $1.5 \mathrm{ml}$ microcentrifuge tube containing $250 \mu \mathrm{l}$ mineral oil kept at room temperature (Olek et al, 1996). One milliliter of $0.2 \mathrm{mg} / \mathrm{ml}$ proteinase $\mathrm{K}$ in $150 \mathrm{~mm}$ $\mathrm{NaCl}, 10 \mathrm{~mm}$ Tris-HCl (pH 8.0), 20 mм EDTA was added to each tube kept at $50^{\circ} \mathrm{C}$ until the shredded samples became translucent (usually for 24-48 hours) in a water bath. After cooling the tubes at room temperature, the agarose beads were treated twice with $1.5 \mathrm{ml}$ of $0.3 \mathrm{~N}$ $\mathrm{NaOH}$ for 15 minutes each, and once with $1.5 \mathrm{ml}$ of 0.1 $\mathrm{N} \mathrm{NaOH}$. To inactivate proteinase $\mathrm{K}$, samples were heated for 15 minutes at $80^{\circ} \mathrm{C}$ and cooled on ice for 5 minutes. One milliliter of freshly prepared bisulfite solution (3.5 $\mathrm{M} \mathrm{NaHSO}_{3}, 1 \mathrm{~mm}$ Hydroquinone, $\mathrm{pH}$ 5.0) was added to the microcentrifuge tubes, and the samples were incubated for 24 hours at $50^{\circ} \mathrm{C}$ under a lightprotected condition. Beads were then washed twice with $1 \mathrm{ml}$ of $10 \mathrm{~mm}$ Tris- $\mathrm{HCl}$ ( $\mathrm{pH}$ 8.0), $10 \mathrm{~mm}$ EDTA for 15 minutes each, and desulfonated by three washes with 1 


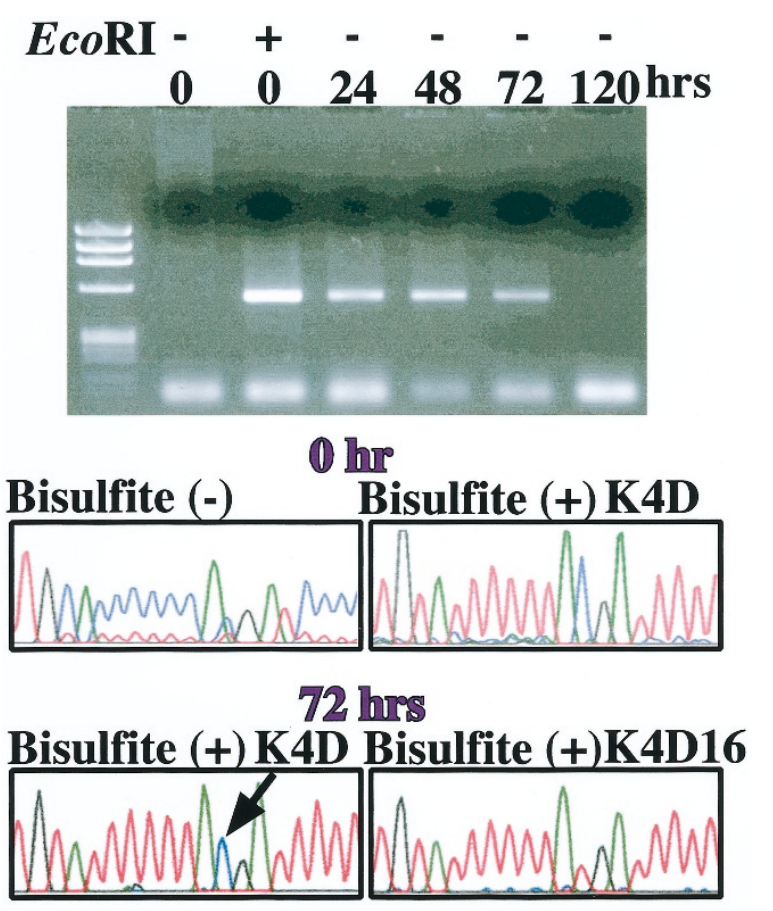

Figure 1.

PCR amplification and sequencing after sodium bisulfite treatment. Lane 1, intact high-molecular-weight DNA; lane 2, intact high-molecular DNA predigested with EcoRI restriction enzyme; lanes 3-6, DNA extracted from K4D cell lines fixed with $10 \%$ formalin for $24,48,72$, and 120 hours, respectively, without restriction enzyme digestion.

ml $0.5 \mathrm{~N} \mathrm{NaOH}$ for 15 minutes each. After neutralization with $200 \mu$ of $1 \mathrm{~N} \mathrm{HCl}$ for 5 minutes, beads were washed twice with $1 \mathrm{ml} 10 \mathrm{~mm}$ Tris- $\mathrm{HCl}(\mathrm{pH} 8.0), 10 \mathrm{~mm}$ EDTA, and finally with nuclease-free water. The beads were sliced into several pieces and used directly as a template for PCR amplification. As shown in Figure 2, a microdissected sample from $A$ showed methylated cytosine at the 20-23rd CpG loci in the 5'-flanking region of the cyclin D1 gene, identifying nodule $A$ with the K4D cell line. On the other hand, a microdissected sample from $B$ showed no methylated cytosine at these CpG loci, indicating that the origin of nodule $\mathrm{B}$ was probably the K4D16 cell line.

Archival formalin-fixed, paraffin-embedded pathological specimens have become increasingly useful in molecular biological studies especially since the introduction of the PCR technique. Tissues stored in paraffin blocks can be a potential source of DNA for retrospective clinicogenic analyses. Formalin-fixation, however, causes various alterations of the nucleic acids, including degradation, due to endogenous nuclease and crosslinking between nucleic acids and proteins. DNA degradation, an inevitable process when DNA is extracted from paraffin blocks, therefore limits the use of such DNA for Southern blot analysis. On the other hand, because of the susceptibility of the template DNA to the formation of complex secondary structures after sodium bisulfite modification, PCR is sometimes difficult when intact high-molecular-weight DNA is used as a template for PCR-mediated detection of methylated cytosine (Frommer et al, 1992). Therefore, DNA degradation, as

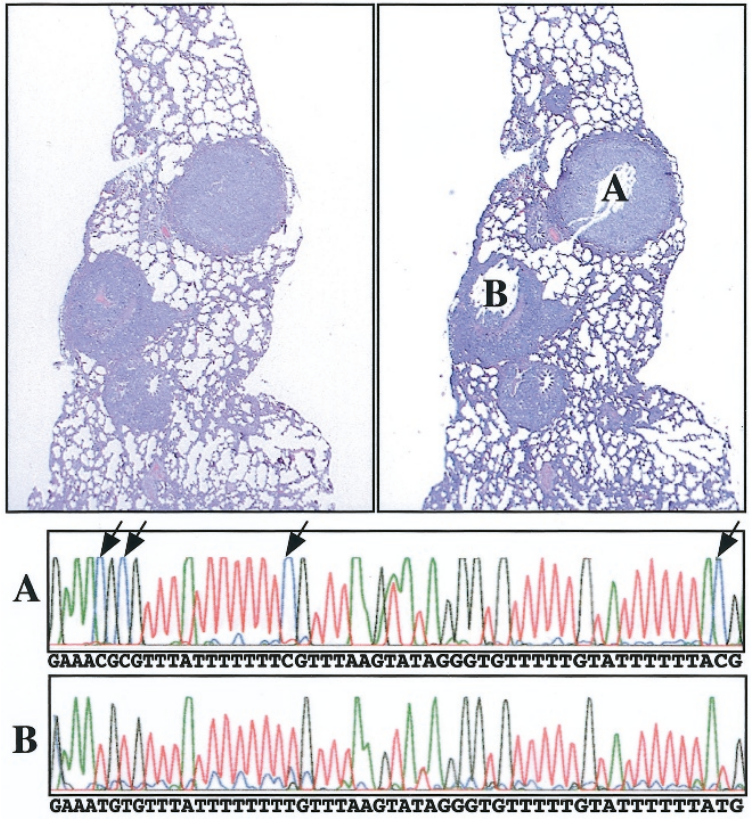

Figure 2.

Detection of methylated cytosine using microdissected fragments from metastatic nodules in the lung. Microdissected samples were taken from areas A and $B(H E \times 100)$. DNA sequencing from area $A$ showed methylated cytosines at the 20-23rd CpG loci identical with the K4D cell line. The absence of these methylated cytosines from area B at these $\mathrm{CpG}$ loci indicated the K4D16 cell line as the probable origin of nodule $B$.

an adverse consequence of formalin-fixation, is an advantage in the PCR-mediated detection of methylated cytosine. Furthermore, once samples are embedded in paraffin, DNA alterations principally stop. Although the possibility of de novo alteration of the methylation status and contamination of the surrounding cells is inevitable, methylation analysis from microdissected section can be a useful alternative technique for clonal analysis. Our study showed the availability and usefulness of routine formalin-fixed, paraffin-embedded pathological specimens as a valuable source for the analysis of methylated cytosine. Retrospective and morphology-oriented epigenetical studies as well as clonal analysis are possible with this technique.

\section{References}

Frommer M, McDonald LE, Millar DS, Collis CM, Watt F, Grigg GW, Molloy PL, and Paul CL (1992). A genomic sequencing protocol that yields a positive display of 5 -methylcytosine residues in individual DNA strands. Proc Natl Acad Sci USA 89:1827-1831.

Kitazawa S, Kitazawa R, and Maeda S (1999). Transcriptional regulation of rat cyclin $\mathrm{D} 1$ gene by $\mathrm{CpG}$ methylation status in promoter region. J Biol Chem 274:28787-28793.

Lewis JD, Meehan RR, Henzel WJ, Maurer-Fogy I, Jeppesen P, Klein F, and Bird A (1992). Purification, sequence, and cellular localization of a novel chromosomal protein that binds to methylated DNA. Cell 69:905-914.

Olek A, Oswald J, and Walter J (1996). A modified and improved method for bisulphite based cytosine methylation analysis. Nucleic Acids Res 24:5064-5066. 